WARNING RESISTANCE OF CULTIVATOR PAWS MODIFIED BY NITROGENATION IN GLOW DISCHARGE

\author{
M. Stechyshyn, M. Luk'yanyuk, V. Oleksandrenko, \\ A. Martynyuk, Yu. Bilyuk \\ Khmelnytsky National University, Khmelnytskyi, Ukraine
}

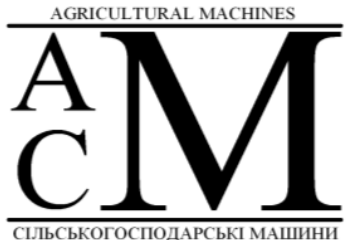

Key words:

cultivator paws, anhydrous nitriding in a glow discharge (BATR), wear resistance, dry friction, work bodies

\section{Article history:}

Received 27.04.2020

Accepted 27.05.2020

Corresponding author: m-mezon@ukr.net

\section{ABSTRACT}

To increase the wear resistance of the tillage tool-paws of the Tiger-Mate 200 cultivator, the technology of anhydrous nitriding in the glow discharge (BATR) of the paws has been developed. As a result of the analysis of the obtained dependences for further research to strengthen the working surface of the cultivator paws, the modification process was carried out in a mode that provides high enough plastic properties of the modified layer to eliminate chipping and chipping of the cultivator paws and blunting during operation, layer: medium $25 \% \mathrm{~N}_{2}+75 \% \mathrm{Ar}$; nitriding temperature $520^{\circ} \mathrm{C}$; pressure in the discharge chamber $200 \mathrm{~Pa}$; duration of nitriding - 6 hours. As a result of applying this method of modification, $a$ surface layer with a thickness of $120 \ldots 150 \mu \mathrm{m}$ with a microhardness of $\mathrm{H100} 950 \ldots 980 \mathrm{MPa}$ based on an elastic base (hardened steel 35G after low-temperature tempering obtained in the process of nitriding $\mathrm{H} 100500 \ldots 600 \mathrm{MPa}$ ) was obtained. Unmodified and modified paws were installed and tested on the cultivator of the Tiger-Mate 200 model in production conditions in the fields of STzOV "Garant" (Khmelnytsky region, Ukraine). In the course of tests change of the sizes of paws in process of their attrition was fixed. The test results confirmed the increase in wear resistance of the modified paws in comparison with the unmodified ones by 1.7 ... 1.8 times.

https://doi.org/10.36910/agromash.vi44.304 
УДК 631.171

\title{
ЗНОСОСТІЙКІСТЬ ЛАП КУЛЬТИВАТОРА, ЩО МОДИФІКОВАНІ АЗОТУВАННЯМ У ТЛІЮЧОМУ РОЗРЯДІ
}

\author{
М.С. Стечишин, М.В. Лук'янюк, В.П. Олександренко, \\ А.В. Мартинюк, Ю.М. Білик
}

Хмельницький національний університет, Хмельницький, Україна

Для підвищення зносостійкості трунтообробних робочих органів розроблена технологія безводневого азотування у тліючому розряді (БАТР) лап культиватора (Tiger-Mate 200). Під час дослідження зміцнення робочої поверхні лап культиватора прочес модифікаиії здійснювався за режимом, що забезпечує достатньо високі пластичні властивості модифікованого шару, щоб виключити сколювання та викришування ріжучого леза лапи культиватора $i$ iї затуплення в прочесі роботи, з одночасним забезпеченням достатньої глибини азотованого шару: середовище - 25\% $\mathrm{N}_{2}+75 \%$ Ar; температура азотування $-520^{\circ} \mathrm{C}$; тиск у розрядній камері - 200 Па; тривалість азотування - 6 год. У результаті застосування иього способу модифікаиії отримано поверхневий шар товщиною $120 \ldots 150$ мкм із мікротвердістю $H_{100} 950 \ldots 980$ МПа, що опирається на пружну основу (гартовану сталь $35 \Gamma$ після низькотемпературного відпуску, отриманого в проиесі азотування $H_{100} 500 \ldots 600$ МПа). Немодифіковані $i$ модифіковані лапи були встановлені та випробовувалися на культиваторі моделі Tiger-Mate 200 у виробничих умовах на полях підприємства СТзОВ “Гарант" (Хмельницька область, Україна). У процесі випробовування фіксувалася зміна розмірів лап (стирання). Результати випробування підтвердили підвищення зносостійкості модифікованих лап $y$ порівнянні із немодифікованими в 1,7...1,8 рази.

Ключові слова: лапи культиватора, безводневе азотування $у$ тліючому розряді (БАТР), зносостійкість, сухе тертя, трунтообробні робочі органи.

\section{Стан питання та постановка проблеми}

Для отримання високих урожаїв сільськогосподарської продукції необхідна якісна обробка грунту. Для обробки грунту застосовуються різноманітні грунтообробні машини, зокрема культиватори. Робочим органом (РО) культиватора $є$ лапи, які внаслідок взаємодії із грунтом піддаються інтенсивному зношуванню. 
На сьогодні існує велика кількість методів підвищення довговічності грунтообробних РО, що передбачають використання різних технологічних підходів і методів їх зміцнення залежно від особливостей грунтів, умов та режимів роботи культиваторів тощо. Вирішенню проблеми підвищення зносостійкості РО грунтообробних машин присвячена значна кількість наукових праць [1 - 5], які вказують на наявність різних підходів до її вирішення. Так, у роботі [2] розрізняють конструктивні, експлуатаційні та технологічні способи підвищення зносостійкості РО грунтообробних машин. До технологічних способів відноситься, насамперед, підбір матеріалів і термообробки, які забезпечують високу зносостійкість в умовах абразивного зношування [1 - 4]. У науковій праці [3] для виготовлення деталей, що працюють в абразивній масі, рекомендовано використовувати матеріали: марганцеві сталі (30Г, 50Г, 65Г, 110Г6Х3Л), сталі леговані хромом (38XА, 40Х, 45Х, Х12, Х12Ф1, Х6ВФ), багатокомпонентні леговані сталі і сплави (12ХН3А, 17ХГ2СФР, 08Х18Н10Т), тверді спечені сплави (ВК6, ВК8, ВК15, ВК20). У праці також відзначається можливість використання двошарового або трьохшарового прокату для підвищення зносостійкості. Поверхневе зміцнення застосовують для підвищення зносостійкості у випадку, якщо до об'ємної міцності деталей не висуваються підвищені вимоги, але необхідна висока поверхнева міцність деталей. Для РО машин, що працюють в абразивній масі, використовують наплавлення таких видів: ручне газове прутковим сплавом типу сормайт №1; дугове порошковою стрічкою; багатоелектродне електрошлакове; плазмове; індукційне. У сільськогосподарському машинобудуванні $90 \%$ усіх робіт зі зміцнення - індукційне наплавлення. Основним недоліком такого методу $є$ висока вартість сплавів для наплавлення [2].

Лапи культиваторів $\epsilon$ однією із найбільш масових деталей РО сільськогосподарських машин. Оскільки лапи культиваторів мають короткий термін служби, відповідно, існує значна потреба у них у вигляді запасних частин, що, у свою чергу, зумовлює необхідність у значній кількості якісного металу для їх виготовлення. Відповідно до технічних вимог, гарантійне напрацювання стрілчастих лап культиватора повинно бути не меншим за 25 га, але, як показує практика експлуатації таких РО, їх напрацювання на відмову на різних грунтах не перевищує $14 \ldots 19$ га. Типовий характер спрацювання лап культиваторів показано на рис. 1.

В Україні серійні РО грунтообробних машин виготовляються зі сталей 65 Г, 45 і Л53, які в загартованому стані (твердість 37...43HRC) 
мають задовільні показники відносного видовження, але невелику межу міцності $\left(\sigma_{6}=880 \ldots 1080\right.$ МПа). За даними багаторічних досліджень і аналізу результатів експлуатаційних випробувань РО грунтообробних машин, лише за перший рік експлуатації із причини зламу (або деформації з наступним зламом) виходять із ладу близько $40 \%$ лемешів і 15\% полиць, 20\% лап культиваторів і $30 \%$ різних типів дискових робочих органів [1].

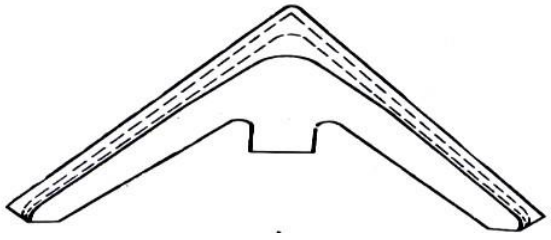

a

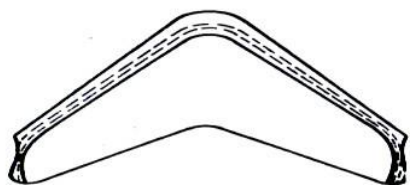

б

Рис. 1 - Спрацювання контуру лап культиватора [1]:

а - із захватом 270 мм; б - із захватом 150 мм

У роботі [5] висловлено припущення, що основна причина виходу із ладу РО грунтообробних машин $є$ недостатня втомна витривалість металів або сплавів РО. Очевидно, що таке припущення має місце для композиційних матеріалів із кераміко-металевими покриттями дискретно-перемінного складу, які характеризуються високим рівнем напружено-деформованого стану і електрохімічною гетерогенністю зміцненої поверхні [6]. Разом із тим, експлуатаційне випробування таких лап показало, що їх довговічність в 1,45 разів вища від серійних і гарантовано забезпечує напрацювання до 32 га.

Дослідження представлені в роботі [1] показали, що на лапах 3 індукційним загартуванням зношування за один сезон роботи досягає 30 мм, при цьому кут їх заточування змінюється з $15^{\circ}$ до $136^{\circ}$ і вони не зрізують, а зминають бур'яни. Крім того, в цьому випадку зростають зусилля на тяговий агрегат, що призводить до підвищення зношування його вузлів і механізмів та зростання витрат паливно-мастильних матеріалів.

Дослідження [7] показує, що застосування для зміцнення лап лазерної термообробки дозволяє в $1,3 \ldots 1,4$ рази знизити зношування деталей різальних елементів у порівнянні з об'ємним гартуванням, а застосування лазерного наплавлення сплаву ПС $-14-60+6 \% \mathrm{~B}_{4} \mathrm{C}$ в $1,7 \ldots 1,8$ рази у порівнянні із базовою технологією індукційного наплавлення. Лазерні технології забезпечують локальне нагрівання за відсутності або мінімальних деформацій при наступному охолодженні 
зміцнених виробів. Отримання високих фізико-механічних властивостей поверхневих шарів пов'язано із високою швидкістю нагрівання та охолодження, що становить $10^{4} \ldots 10^{6} \mathrm{C} / \mathrm{c}$.

Загалом, можна констатувати, що для більшості регіонів України одного комплекту деталей РО грунтообробних машин недостатньо на поточний річний цикл (весна + осінь), а тому потрібно продовжувати пошуки нових, економічно обгрунтованих методів і способів поверхневого зміцнення РО грунтообробних машин.

Мета дослідження - пошук способів і методів підвищення зносостійкості РО грунтообробних машин шляхом застосування прогресивних технологій поверхневого зміцнення, а саме безводневого азотування у тліючому розряді (БАТР).

\section{Матеріали і методи}

Дослідження процесу БАТР проводилося в лабораторії Подільського наукового фізико-технологічного центру (ПНФТЦ) в Хмельницькому національному університеті (ХНУ) на експериментальній установці ИПАС-63, яка забезпечує зміцнення як зразків, так і промислових деталей діаметром до 400 мм і довжиною до 1000 мм (рис. 2).

Кожен режим азотування складався із циклу операцій: підготовчі операції до зміцнення (очистка камери і деталей від іржі, окалини, знежирення поверхонь) та проведення процесу зміцнення (створення вакууму в камері $10^{-2}$ мм рт. ст., продувка камери робочою сумішшю, відкачування суміші, очищення деталей за напруги 1200 В, запуск робочої суміші, проведення основного режиму за встановлених значень тиску і температури).
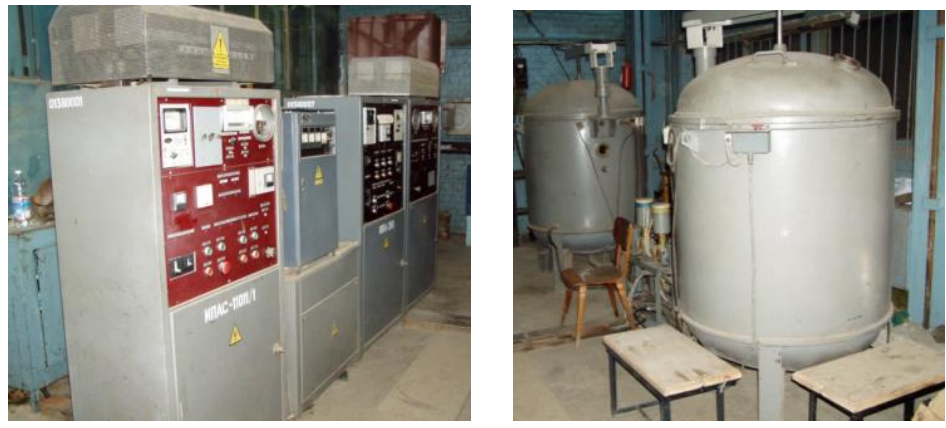

Рис. 2 - Установки азотування у тліючому розряді ИПАС-63 (варіант двокамерної установки) 
На Шепетівському культиваторному заводі (Україна) лапи культиваторів виготовляються із високовуглецевої сталі (65Г, ГОСТ1050-88, що відповідає ДСТУ 7809:2015). Нами досліджувалися ножі культиватора Tiger-Mate 200 закордонного виробництва із метою підвищення їх зносостійкості. Лабораторним аналізом було встановлено, що ножі виготовлені із матеріалу, який відповідає вітчизняній марці легованої сталі $35 \Gamma$.

Дослідження проводилися у два етапи: на першому етапі випробування на зносостійкість проводили на зразках, виготовлених із матеріалу відпрацьованих лап, а на другому етапі - на натурних зразках у виробничих умовах. Зносостійкість визначали на універсальній машині тертя 2168 УМТ у режимі сухого тертя із закріпленим абразивом. Форма та розміри дослідного зразка представлені на рис. 3. Режим сухого тертя застосовувався із метою інтенсифікації процесу зношування зразків та зменшення часу проведення випробувань.

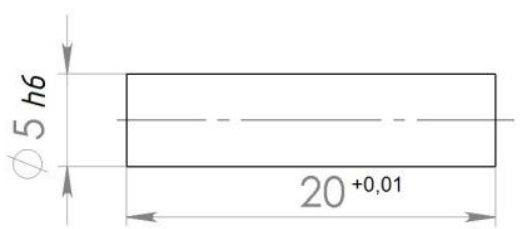

Рис. 3 - Ескіз зразка для проведення досліджень на зносостійкість

Дослідження проводили із використанням металографічного, електронно-мікроскопічного методів, методу феромагнітного резонансу та рентгеноструктурного аналізу [8]. Структуру дифузійного шару в перерізі і розподіл мікротвердості за товщиною шару вивчали на травлених шліфах. Субмікроскопічну структуру нітридної зони вивчали на растровому електронному мікроскопі РЭМ-200. Рентгеноструктурний фазовий аналіз поверхневих шарів зразків здійснювали на рентгенівському дифрактометрі ДРОН-200 iз використанням $k_{\alpha}$ випромінювання. Товщина карбоазотованого шару визначалась металографічним методом за допомогою мікроскопа MIM-10 та шляхом вимірювання мікротвердості за глибиною зміцненого зразка.

\section{Результати дослідження та обговорення}

Рентгеноструктурним аналізом встановлено, що незалежно від складу газової атмосфери в поверхневому шарі утворюється $\varepsilon$-фаза $\left(\mathrm{Fe}_{2-3} \mathrm{~N}\right), \quad \gamma$-фаза $\left(\mathrm{Fe}_{4} \mathrm{~N}\right)$ і $\alpha$-фаза. Фазовий склад і співвідношення 
фазових структур в азотованому шарі можна регулювати шляхом зміни режимних параметрів азотування: температури $T$, вмісту азоту $C$ і тиску газової суміші $P$ (рис. 4). Аналіз отриманих залежностей показує, що найбільш суттєво впливає на кількість утворення тих чи інших фаз температура $T$ процесу іонного азотування. Так, із іiі підвищенням, зменшується кількість $\varepsilon$-фази (рис. 4, а) в поверхневому шарі і одночасно збільшується кількість $\gamma^{\prime}$-фази і $\alpha$-фази (рис. $4, \sigma$, в). Iз збільшенням вмісту $C$ азоту і тиску $P$ газової суміші збільшується кількість $\varepsilon$-фази (рис. 4, а) і зменшується кількість $\gamma^{\prime}$-фази (рис. 4, б). При цьому вміст $C$ азоту і тиск $P$ газової суміші практично не впливають на вміст $\alpha$-фази (рис. 4, в), кількість якої контролюється лише температурою $T$ іонного азотування у тліючому розряді, яка, у свою чергу, залежить від енергетичних характеристик процесу (густини струму і напруги на електродах газорозрядної камери)

Ураховуючи суттєву різницю між фізико-хімічними властивостями фазових структурних складових азотованого шару i можливість регулювання їх кількості та співвідношення між ними, з'являються широкі можливості отримання шарів із заданими характеристиками поверхонь.

Як показали дослідження [8 - 13], структура шару і його фазовий склад визначають експлуатаційні характеристики виробів. Зокрема, для відкритих пар тертя (зубчасті колеса, зірочки ланцюгових передач, пальці конвеєрів тощо) застосовуються деталі із високою твердістю, сформовані на базі $\varepsilon$-фази $\left(\mathrm{Fe}_{2} \mathrm{~N}\right)$. Для закритих пар тертя (підшипники ковзання, зубчасті колеса, коробки передач тощо) необхідне формування азотованого шару із розвинутою нітридною зоною, яка складається із малоазотистих пластичних нітридних фаз $\gamma$ i $\gamma^{\prime}\left(\mathrm{Fe}_{3} \mathrm{~N} \mathrm{i}\right.$ $\mathrm{Fe}_{4} \mathrm{~N}$ ), які добре приробляються та локалізують пластичні деформації і перешкоджають розвитку процесу руйнування деталі.

Найбільший вплив на підвищення границі витривалості за знакозмінних навантажень має зона внутрішнього азотування ( $\alpha$-фаза). На підвищення жароміцності найбільший вплив також має зона внутрішнього азотування, але 2-го роду, тобто коли утворюються нітриди легуючих елементів $\mathrm{TiN}, \mathrm{ZrN}$ i $\mathrm{HfN}$ [3].

Вакуумно-дифузійні процеси іонного азотування у тліючому розряді протікають в $1,5 \ldots 2$ рази інтенсивніше, ніж за пічного азотування, що і визначає нові властивості іонно-азотованих шарів [9, 10]. Згідно $[11,12]$ через 4 год. настає рівновага між розпилюванням i осадженням іонів азоту, а тому основні дослідження властивостей азотованих поверхонь були проведені за тривалості процесу азотування 4 год. 
Ураховуючи, що мікротвердість $є$ важливою характеристикою зносостійкості за абразивного зношування і зміна мікротвердості за товщиною дифузійного шару характеризує співвідношення та розподіл структурних i фазових складових покриття, а також $\epsilon$ мірою енергоємності поверхневих шарів [8], тому досліджено вплив параметрів іонного азотування на зміну мікротвердості (рис. 5, а, б).

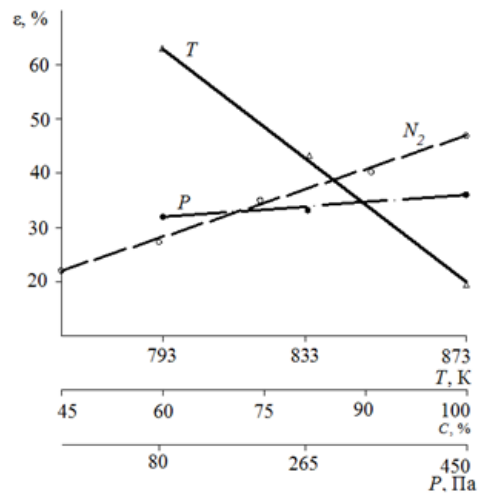

a

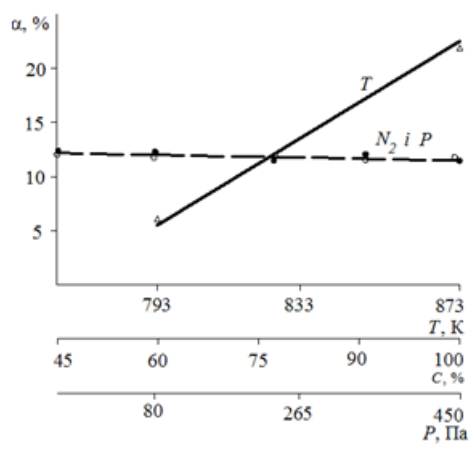

B

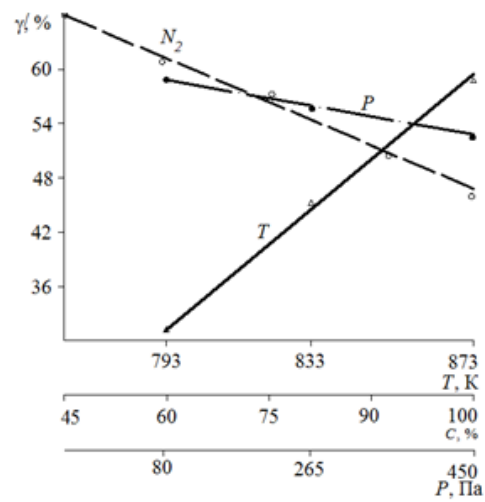

б
Рис. 4 - Залежність фазового складу дифузійного шару сталі $45 \mathrm{X}$ від режимів іонного азотування (температура $T$, вміст азоту $C$ і тиск газової суміші $P$ ): а- вміст $\varepsilon$-фази; б-вміст $\gamma$-фази; в- вміст $\alpha$-фази

Аналіз отриманих результатів досліджень дозволив сформулювати загальні закономірності зміни мікротвердості нітридної зони залежно від зміни параметрів режиму азотування:

1) максимальна твердість підвищується із підвищенням вмісту вуглецю і кількості та виду легуючих елементів основи (криві 1, 2, 3 на рис. 5, а); наявність легуючих, особливо нітридоутворюючих елементів 
має набагато більший вплив на величину мікротвердості, ніж вуглець (криві 1, 2, 3 на рис. 5, а);

2) із підвищенням температури азотування мікротвердість нітридної зони знижується, причому швидкість зниження мікротвердості підвищується із збільшенням ступеня легування i iз вмістом вуглецю основи;

3) із збільшенням вмісту азоту і тиску газового середовища мікротвердість зростає, але швидкість зростання набагато менша за швидкість іiї зниження при підвищенні температури;

4) збільшення часу азотування (за незмінних температури, тиску i складу газової суміші) без зміни величини мікротвердості сприяє більш плавному іiі переходу до твердості основи 3 одночасним розширенням зони дії підвищених значень мікротвердості (рис. 5, б).

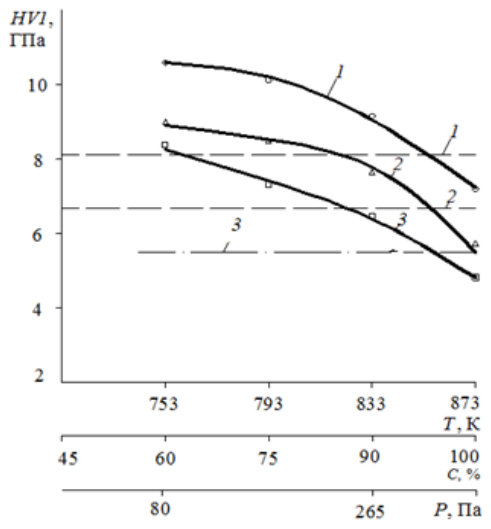

a

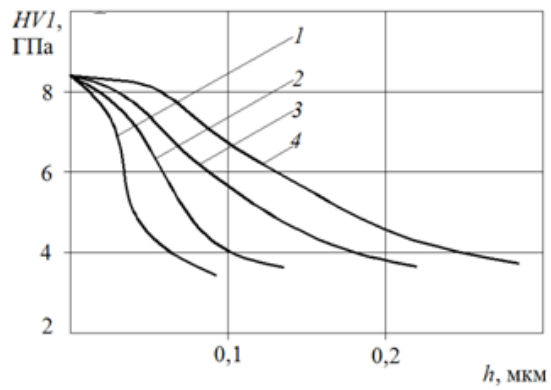

б

Рис. 5 - Графічні залежності:

a - мікротвердості нітридної зони від параметрів: температури $T, \mathrm{~K}$

(суцільні лінії); вмісту азоту $C, \%$ (штрихові лінії); тиску газової суміші $P$, Па (штрих-пунктирні лінії) для сталей: 1 - 38ХМЮА; 2 - сталь 40Х; 3 - сталь 35Г;

б - розподіл мікротвердості $H V l$ за товщиною дифузійного азотованого шару зразків сталі $40 \mathrm{X}$ протягом:

$$
1 \text { - } 1 \text { год.; } 2 \text { - } 2 \text { год.; } 3 \text { - } 3 \text { год.; } 4 \text { - } 4 \text { год. }
$$

Максимальна мікротвердість нітридної зони отримана на сталі 38ХМЮА внаслідок того, що нітриди легуючих елементів мають вищу твердість, дисперсність, термічну стійкість порівняно із нітридами заліза, а зниження мікротвердості із підвищенням температури 
азотування пояснюється зниженням степені дискретності нітридів. Внаслідок того, що нітриди заліза відрізняються невеликою термічною стійкістю і великою швидкістю коагуляції [3], твердість вуглецевих сталей мало залежить від температури азотування (крива 3 - рис. 5, а).

Згідно даних [9], дисперсність включень нітридів легуючих елементів чинить вирішальний вплив на величину $\mathrm{i}$ розподіл мікротвердості за товщиною азотованого шару. Так, дослідження тонкої структури азотованої сталі $40 \mathrm{X}$ за допомогою растрового електронного мікроскопу РЕМ-200 показали, що за підвищення температури азотування із $833^{\circ} \mathrm{K}$ до $873^{\circ} \mathrm{K}$ площа поверхні нітридів збільшується в середньому у 38 разів і, відповідно, знижується мікротвердість.

Отримані результати підтверджуються даними рентгеноструктурного аналізу. Відомо, що максимальна мікротвердість азотованого шару відповідає утворенню когерентних зародків нітридної фази, що викликають найбільші спотворення кристалічної гратки матриці, усереднене значення яких характеризується шириною і інтенсивністю дифракційних максимумів $\alpha$-фази. Із збільшенням температури азотування i зростанням нітридних часток когерентність порушується, спотворення гратки матриці і твердість шару зменшуються (рис. 5, а).

Легуючі елементи, підвищуючи розчинність азоту в легованій $\alpha$ фазі, зумовлюють зменшення коефіцієнта його дифузії і призводять до зменшення товщини дифузійного шару. Також товщина зменшується iз збільшенням вуглецю матриці. При цьому концентрація азоту в поверхневому шарі $\varepsilon$-фази змінюється незначно. Так, кількість $\varepsilon$-фази для сталі 20 становила 19\%, а для сталі $45-21 \%$ [11].

Ураховуючи отримані залежності, під час проведення досліджень із модифікації робочої поверхні лап культиватора процес модифікації здійснювався за режимом, що забезпечує достатньо високі пластичні властивості модифікованого шару, щоб виключити сколювання та викришування ріжучого леза лапи культиватора та їі затуплення в процесі роботи, із забезпеченням достатньої глибини азотованого шару: середовище $-25 \% \mathrm{~N}_{2}+75 \% \mathrm{Ar}$; температура азотування $520^{\circ} \mathrm{C}$; тиск у розрядній камері - 200 Па; тривалість азотування - 6 год.

У результаті застосування цього способу модифікації отримано поверхневий шар товщиною $120 \ldots 150$ мкм із мікротвердістю $\mathrm{H}_{100} 950 \ldots 980$ МПа, що опирається на пружну основу (гартована сталь 35Г після низькотемпературного відпуску, отриманого в процесі азотування $\mathrm{H}_{100} 500 \ldots 600$ МПа) [13]. 


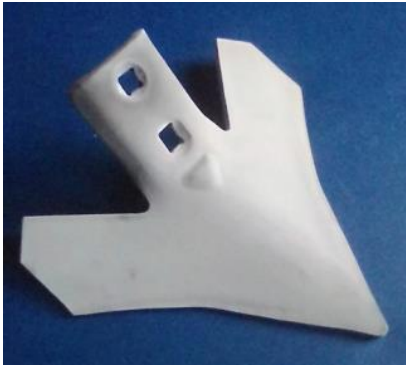

Рис. 6 - Зовнішній вигляд лапи культиватора, що модифікована азотуванням у тліючому розряді
Немодифіковані та модифіковані лапи були встановлені та випробовувалися на культиваторі моделі Tiger-Mate 200 у виробничих умовах на полях підприємства СТзОВ "Гарант" (Хмельницька область, Україна). У процесі випробовувань фіксувалася зміна розмірів лап (стирання) під час їх експлуатації. Результати випробувань підтвердили підвищення зносостійкості модифікованих лап у порівнянні із немодифікованими в $1,7 \ldots 1,8$ рази. Зовнішній вигляд лапи культиватора, що зміцнена безводневим азотуванням у тліючому розряді, показано на рис. 6 .

\section{Висновки}

1. На основі проведених досліджень і аналізу літературних джерел обгрунтовано важливість та актуальність вивчення тонких механізмів протікання процесів безводневого азотування металів у тліючому розряді для їх практичного застосування шляхом оптимальної комбінації параметрів технологічного режиму із пріоритетом енергетичних підходів.

2. Сформульовані загальні закономірності зміни мікротвердості нітридної зони залежно від автономних параметрів режиму азотування та проведено їх обгрунтування за результатами рентгеноструктурного аналізу фазового складу азотованих поверхонь.

3. Аналіз результатів проведених досліджень із підвищення зносостійкості лап культиватора шляхом їх безводневого азотування у тліючому розряді показав доцільність та перспективність застосування цього методу хіміко-термічної обробки для модифікації РО грунтообробних машин.

\section{Список посилань}

1. Денисенко, М. I. Зміцнення лез грунтообробних робочих органів сільськогосподарських машин 3 утворенням ефекту самозагострювання / М. І. Денисенко, В. Д. Войтюк // Технічний сервіс агропромислового, лісового та транспортного комплексів. 2016. - № 6. - С. 175-182.

2. Борак, К. В. Підвищення надійності робочих органів грунтообробних машин / К. В. Борак // Вісник Харківського 
національного технічного університету сільського господарства імені Петра Василенка. - 2015. - Вип. 163. - С. 120-125.

3. Синеоков, Г. Н. Теория и расчет почвообрабатывающих машин / Г. Н. Синеоков, И. М. Панов. - М. : Машиностроение, 1977. - 328 с.

4. Волков, Ю. В. Долговечность машин работающих в абразивной среде / Ю. В. Волков, 3. А. Волкова, Л. М. Кайгородцев. - М. : Машиностроение, 1994. - 117 с.

5. Саінсус, О. Д. Підвищення довговічності лап культиваторів композиційними покриттями перемінного складу : автореф. дис. на здобуття наук. ступеня канд. техн. наук : спец. 05.05.11 "Машини i засоби механізації сільськогосподарського виробництва" / Саінсус Олександр Дмитрович; Кіровоград. нац. техн. ун-т. - Кіровоград, 2008. -20 c.

6. Стечишин, М. С. Корозія і захист від корозії : навчальний посібник / М. С. Стечишин, В. П. Олександренко, Ю. М. Білик. Хмельницький : ХНУ, 2015. - 197 с.

7. Бобрицький, В. М. Підвищення зносостійкості різальних елементів робочих органів грунтообробних машин : автореф. дис. на здобуття наук. ступеня канд. техн. наук : спец. 05.02.04 "Тертя та зношування в машинах" / Бобрицький Віталій Миколайович; Національний транспортний університет. - Київ, 2007. -20 с.

8. Stechyshyn, M. S. Influence of the ionic nitriding of steels in glow discharge on the structure and properties of the coatings / M. S. Stechyshyn, A. V. Martynyuk, Y. M. Bilyk, V. P. Oleksandrenko, N. M. Stechyshyna // Materials Science. - 2017. - 53 (3). - P. 343-349.

9. Лахтін, Ю. М. Структура и прочность азотированих сплавов / Ю. М. Лахтин, Я. Д. Коган. - М. : Металлургия, 1992. - 176 с.

10. Арзамасов, Б. Н. Ионная химико-термическая обработка сплавов / Б. Н. Арзамасов, А. Г. Братухин, Ю. С. Елисеев, Т. А. Панайоти. М. : Изд-во МГТУ им. Н. Э. Баумана, 1999. - 400 с.

11.Каплун, В. Г. Ионное азотирование в безводородных средах : монография / В. Г. Каплун, П. В. Каплун. - Хмельницкий : ХНУ, 2015. $-315 \mathrm{c}$.

12. Пастух, И. М. Теория и практика безводородного азотирования в тлеющем разряде / И. М. Пастух. - Харьков : ННЦ ХФТИ, 2006. $364 \mathrm{c}$.

13. Стечишин, М. С. Розробка і дослідження низькотемпературних газорозрядних технологій у подільському науковому фізикотехнологічному центрі / М. С. Стечишин, М. В. Лукянюк, В. П. Олександренко, М. М. Лук'янюк // Вісник ХНУ : Хмельницький. 2019. - №3. - C. 6-12. 